\title{
Immune enhancement activities of silk lutein extract from Bombyx mori cocoons
}

\author{
Porkaew Promphet ${ }^{1}$, Sirirat Bunarsa ${ }^{2}$, Manote Sutheerawattananonda ${ }^{3}$ and Duangkamol Kunthalert ${ }^{2,4^{*}}$
}

\begin{abstract}
Background: Declining immune function poses an important clinical challenge worldwide and supplementation with natural products that possessing immune enhancing properties is a promising approach for preventing or delaying immune function decline. Cocoons from yellow silkworms are a significant source of lutein, and this unexplored silk extract could be a viable alternative source for dietary lutein. This study assessed immunomodulatory activities of the silk lutein extract. Female BALB/c mice orally received lutein, either as silk or marigold extracts $(10$ or $20 \mathrm{mg} / \mathrm{kg}$ daily), or vehicle only (1\% tween 80 in PBS pH 7.4) for 4 weeks. Natural killer (NK) cell activity, specific antibody production, lymphocyte subpopulations, mitogen-induced lymphocyte proliferation, and cytokine production were examined.

Results: Silk lutein extract increased NK cell activity, and the effect was dose-related whereas marigold lutein extract was ineffective. Silk lutein extract dose-dependently enhanced antibody production in pre-immunized mice but marigold lutein extract had no effect. Feeding with silk lutein extract increased the populations of CD3+ and CD4 + CD3 + cells. Silk lutein extract also stimulated concanavalin A- and lipopolysaccharide-induced proliferations of T and B lymphocytes, respectively. Moreover, silk lutein extract increased IL-2 and IFN- $\gamma$ production while the effect of marigold lutein extract was undetectable.
\end{abstract}

Conclusions: Together, silk lutein extract enhanced both innate and adaptive immune functions. This preparation may prove to be an effective supplement for strengthened immunity.

Keywords: Antibody production, BALB/c mice, Immune function, Interleukin-2, Natural killer cells, Silk lutein extract

\section{Background}

Immune functions are indispensable as they are the host defenses against infections and cancers, and therefore play a crucial role in maintaining health. Declining immune functions that occur as a result of aging, chronic illnesses, physical and mental stress or unhealthy lifestyles is a major clinical problem globally. Supplementing the immune system with natural products that possess immune enhancing activities is a promising approach for preventing decline of immune functions. Nonprovitamin A carotenoids, notably lutein, have attracted great interest over the decades [1]. The xanthophyll lutein has been noted for its importance in preventing age-related macular degeneration [2-4], cataracts [5], UV-induced skin damage [6], and tumor growth [7-9]. Accumulated evidence to date has also interestingly

\footnotetext{
* Correspondence: kunthalertd@yahoo.com

2Department of Microbiology and Parasitology, Faculty of Medical Science,

Naresuan University, Phitsanulok 65000, Thailand

${ }^{4}$ Centre of Excellence in Medical Biotechnology, Faculty of Medical Science,

Naresuan University, Phitsanulok 65000, Thailand

Full list of author information is available at the end of the article
}

indicated that lutein has a role in regulating immune functions [1]. For instance, it increases phytohemagglutinin (PHA)-stimulated lymphocyte proliferation [8] and enhances antibody production in response to T-dependent antigen in murine spleen cells [10]. Studies that used animals, which are inefficient converters of carotenoids to vitamin A, also supported the immune regulating role of lutein $[11,12]$. Dietary lutein supplementation has been shown to stimulate both humoral and cellular immunity in cats, dogs as well as zebra finches [11-13]. The use of lutein has been increasingly recommended by some physicians as well as more generally used by the public as a dietary supplement [14-16].

Human cannot synthesize lutein and uptake is therefore dependent on the consumption of diet including certain fruits, leafy green vegetables and egg yolks [17]. Lutein used in most studies as well as that contained in most commercial dietary supplements is obtained from marigold flowers. Alternative sources of lutein have, however, continuously been investigated $[18,19]$. Yellow cocoons of 
silkworms, Bombyx mori have gathered increasing attention on the grounds of studies that reported to contain a significant amount of the carotenoid pigments [20]. Up to $88 \%$ of carotenoids in yellow silk cocoons is the xanthophyll lutein [21]. Providing that, the silk lutein extract from yellow cocoons could alternatively become a valuable dietary resource and may expand uses of lutein in the field of medicine, especially in immune modulating therapies.

The present study was therefore designed to investigate the effects of such yellow silk lutein extract in modulating immune functions that require both innate and adaptive systems to work in concert. The effects of an equivalent content of lutein derived from marigold extract were also examined. While previous research showed actions only on the adaptive arm, this study also examined innate immune responses to silk lutein extract, and it was found that there was selectively increased NK cell and T and B lymphocyte activities.

\section{Results}

\section{Body weights, and spleen and thymus indices}

Daily oral administration of lutein extracts either from silk cocoons or from marigolds produced no signs of ill-health (behavior, body coat, feces, etc.), no mortalities, and no differences in body weights. In addition, there were no differences in the spleen and thymus indices between the control and treatment groups throughout the study (data not shown).

\section{Effect on natural killer cell activity}

The oral administration of silk lutein extract (10 and $20 \mathrm{mg} /$ $\mathrm{kg})$ for 2 weeks clearly increased $(\mathrm{P}<0.01)$ the activity of NK cells, and these effects appeared to be dose related as demonstrated in Figure 1. In contrast, none of the samples from the animals treated with marigold lutein extract appeared to show any change.

\section{Effect on splenic lymphocyte subpopulations}

Alterations in the percentages of lymphocyte subsets were observed after lutein extract administration and illustrated in Figure 2. Oral administration of silk lutein extract consecutively for 4 weeks did not influence the percentages of $\mathrm{CD} 21 / 35+\mathrm{B}$ cells and $\mathrm{CD} 8+\mathrm{CD} 3+\mathrm{T}$ cytotoxic (Tc) (Figure $2 \mathrm{~A}$ and $2 \mathrm{D}$ ). However, significant increases in the percentage of CD3+ total $\mathrm{T}$ cells $(\mathrm{P}<0.05)$ and CD4 + CD3 + T helper (Th) cells $(\mathrm{P}<0.01)$ were detected in mice fed $20 \mathrm{mg} / \mathrm{kg}$ silk lutein extract compared to the control (Figure 2B and 2C). In contrast, mice in the marigold lutein extract treated groups did not show any differences in total $\mathrm{T}$ and $\mathrm{Th}$ populations throughout the 4-week period and this have previously been described elsewhere [22].

\section{Effect on mitogen-induced lymphocyte proliferation} Silk lutein extract (10 and $20 \mathrm{mg} / \mathrm{kg}$ ) significantly enhanced the ConA-induced proliferative response of splenic lymphocytes, but this did not appear to be dose related (Figure 3A). Marigold lutein extract $(20 \mathrm{mg} / \mathrm{kg}$ ) also showed such proliferative effects. For LPS $(2.5 \mu \mathrm{g} / \mathrm{ml})$ as the challenge, increased $(\mathrm{P}<0.05)$ lymphocyte proliferative responses were observed in mice fed silk lutein extract (10 and $20 \mathrm{mg} / \mathrm{kg}$ ) and marigold lutein extract $(20 \mathrm{mg} / \mathrm{kg}$ ) (Figure 3B). Furthermore, the magnitudes of the lymphocyte proliferations were found to be similar in all of these lutein extract treated groups.

\section{Effect on cytokine production}

The production of cytokines measured from the supernatants of ConA-stimulated splenic cultures from mice fed lutein extracts from silk cocoons or marigolds are illustrated in Table 1. Mice fed 10 and $20 \mathrm{mg} / \mathrm{kg}$ silk lutein extract had significantly increased $(\mathrm{P}<0.05$ and $\mathrm{P}<0.01$, respectively) levels of IL-2 compared to the control mice. Elevated levels of IFN- $\gamma$ were also observed in the silk lutein extract treated groups compared to the controls. In contrast, the marigold lutein extract treated animals (10 and $20 \mathrm{mg} / \mathrm{kg}$ ) showed no differences in such cytokine production. No treatment differences in the levels of IL-4 and IL-10 cytokines were found after the 4-week period (data not shown).

\section{Effect on specific antibody production}

The effect of lutein extracts from silk cocoons or marigolds on the production of specific antibodies was determined by measuring anti-sheep erythrocyte antibody titers. As shown in Figure 4, mice fed 10 or $20 \mathrm{mg} / \mathrm{kg}$ silk lutein extract had significantly higher $(\mathrm{P}<0.01)$ concentrations of anti-sheep erythrocyte antibodies than the control mice. Administration of marigold lutein extract at the dosages of 10 or $20 \mathrm{mg} / \mathrm{kg}$ did not result in elevated antibody titers.

\section{Discussion}

By assessing the key immune parameters in a BALB/C mouse, an appropriate animal model for immunomodulatory study of carotenoids [23], the present work demonstrated that silk lutein extract significantly enhanced the immune functions, both innate and adaptive arms. The antibody response to a specific antigen (the sheep erythrocytes herein) was clearly increased by the silk lutein extract while the marigold lutein extract had no effect. For the specific immune cell responses, a more complex picture emerges with the yellow silk lutein extract. (i) For NK cells, the enhancements of NK activity were apparent as early as 2 weeks after the initiation of lutein extract administration. To our knowledge, this is the first time such luteincontaining extract stimulation of NK cells has been identified. Since NK cells are anti-tumor and antiviral hunter-killers, our findings would suggest the potential for silk lutein extract to augment NK cell surveillance. (ii) There was an indication of an elevated percentage of total T cells, which was reflected in the Th subset but not the Tc; and 


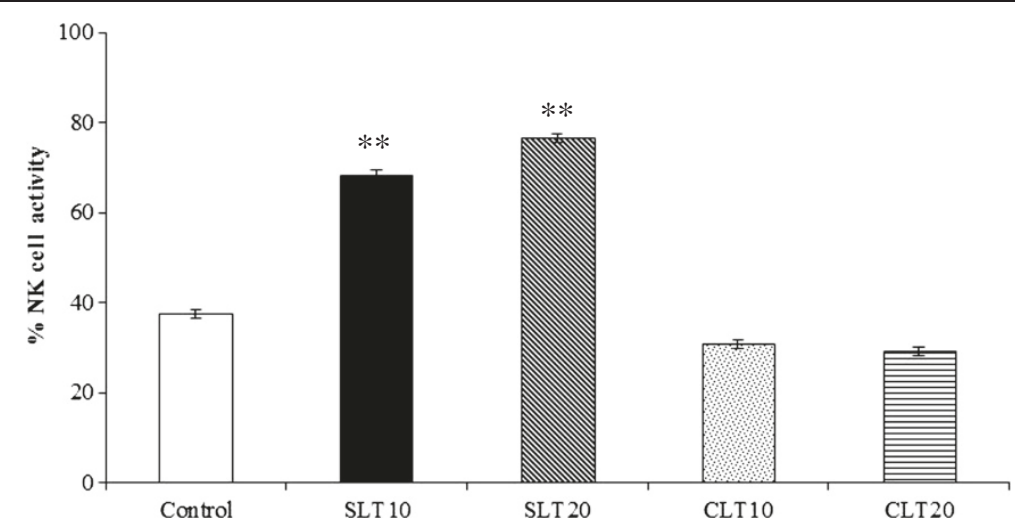

Figure 1 Effect of silk lutein extract and marigold lutein extract on NK cell activity. Splenic cells were isolated from BALB/C mice fed lutein extracts from silk cocoons or marigolds daily for 2 weeks and cultured with YAC-1 cell line at a ratio of 100: 1. After 20 hours in a $37^{\circ} \mathrm{C}$ and $5 \%$ $\mathrm{CO}_{2}$ incubator, activity of NK cells was determined by MTT assay. Values represent means \pm SEM. ${ }^{* *} \mathrm{P}<0.01$ compared to the control. SLT10, SLT20; silk lutein extract 10 and 20 mg/kg groups, CLT10, CLT20; marigold lutein extract 10 and 20 mg/kg groups.

(iii) T cells secreted IL-2 and IFN- $\gamma$ and their increased levels were consistent with the lymphocyte stimulation.

Mitogen-induced lymphocyte proliferation is a powerful indicator of adaptive immune functions. In the present study, silk lutein extract strengthened the splenic lymphoproliferative response to ConA after 4 weeks of administration. Such lymphocyte stimulation accords with the increased $\mathrm{CD} 3+$ total $\mathrm{T}$ and $\mathrm{CD} 4+\mathrm{CD} 3+\mathrm{Th}$ cell counts (Figure 2). Interestingly, only silk lutein extract stimulated the production of IL-2. Therefore,

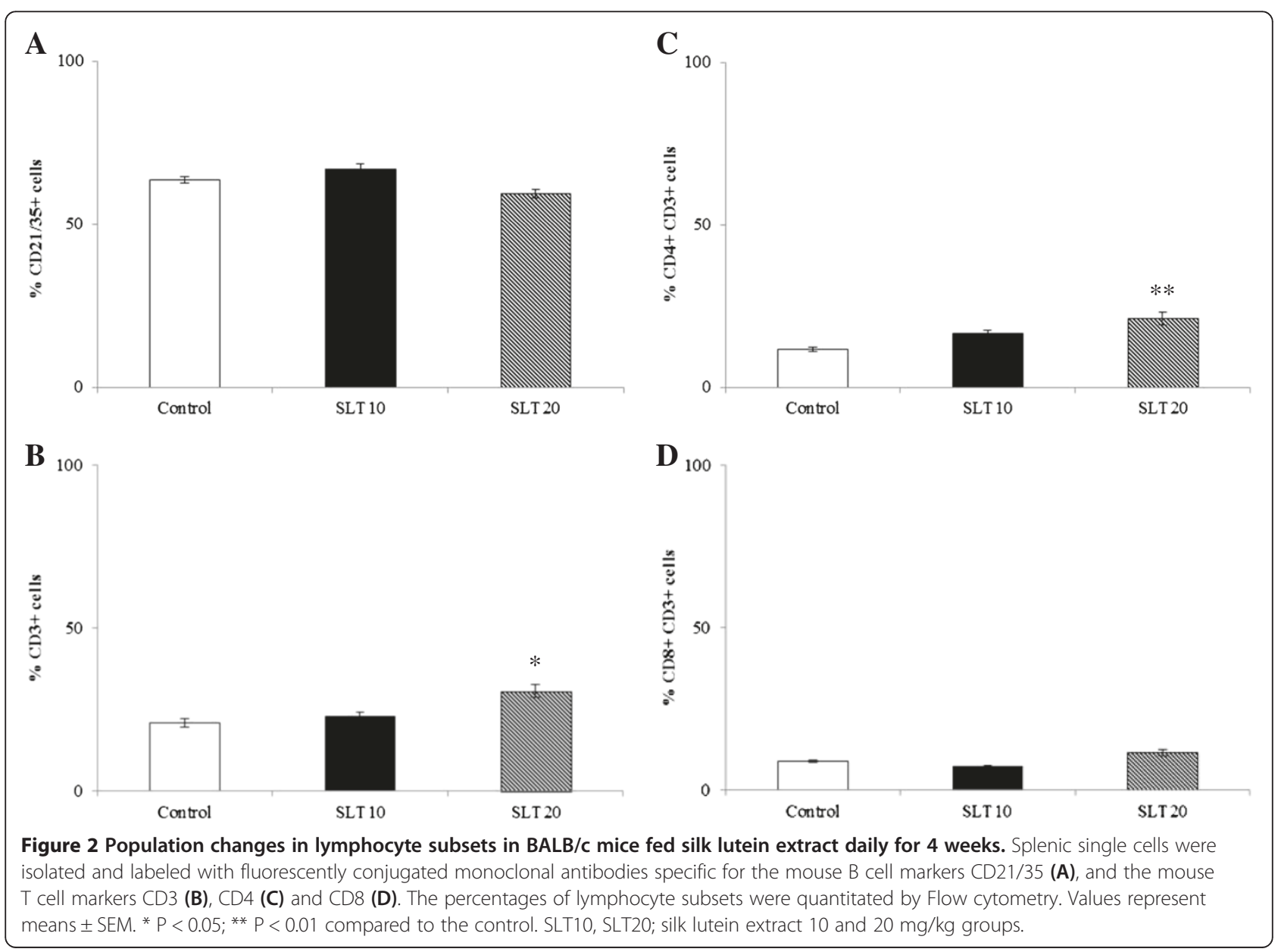



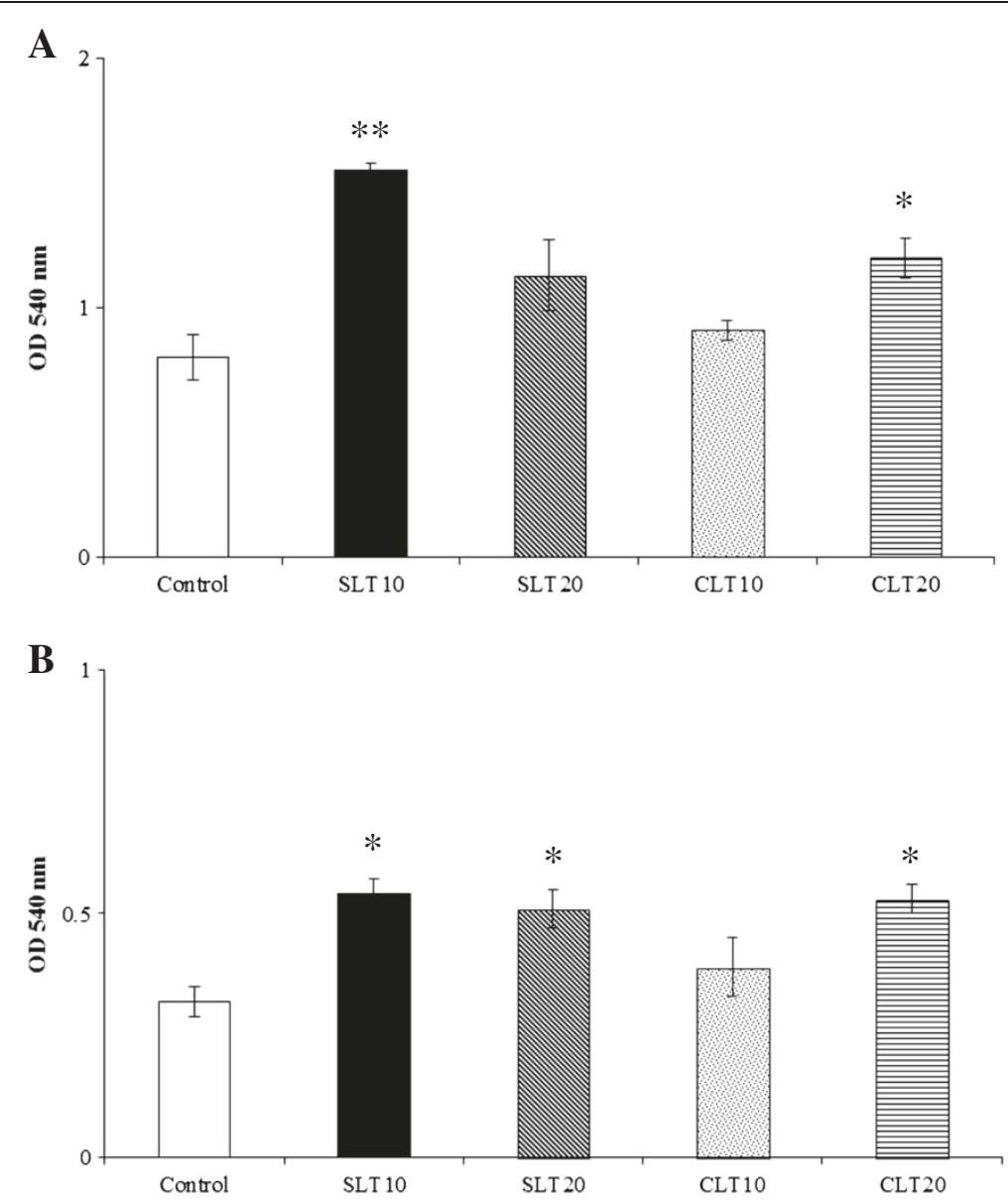

Figure 3 Effects of silk lutein extract and marigold lutein extract on in vitro lymphocyte proliferation. Splenic cells were isolated from $\mathrm{BALB} / \mathrm{C}$ mice fed lutein extracts from silk cocoons or marigolds daily for 4 weeks and cultured in the presence of ConA (A) or LPS (B) at $37^{\circ} \mathrm{C}$ in a $5 \% \mathrm{CO}_{2}$ incubator. After 20 hours, MTT assay was performed. Values represent means $\pm \mathrm{SEM}$. ${ }^{*} \mathrm{P}<0.05 ;{ }^{*} \mathrm{P}<0.01$ compared to the control. SLT10, SLT20; silk lutein extract 10 and 20 mg/kg groups, CLT10, CLT20; marigold lutein extract 10 and 20 mg/kg groups.

Table 1 In vitro cytokine production by splenic cells from BALB/c mice fed with lutein extracts from silk cocoons or marigolds daily for 4 weeks ${ }^{1}$

\begin{tabular}{ccc}
\hline Treatment group & \multicolumn{2}{c}{ Cytokine concentration $(\mathbf{p g} / \mathbf{m l})$} \\
\cline { 2 - 3 } & $\mathbf{I L - 2}$ & IFN- $\boldsymbol{\gamma}$ \\
\hline Control & $102.4 \pm 25.4$ & $1874.4 \pm 304.0$ \\
SLT10 & $187.1 \pm 18.9^{*}$ & $2568.2 \pm 233.5$ \\
SLT20 & $219.3 \pm 11.9^{* *}$ & $2265.6 \pm 162.3$ \\
CLT10 & $97.5 \pm 15.2$ & $1037.8 \pm 274.1$ \\
CLT20 & $97.5 \pm 3.7$ & $1787.8 \pm 188.9$
\end{tabular}

${ }^{1}$ Splenic cells from mice fed with lutein extracts from silk cocoons or marigolds were cultured with ConA at $37^{\circ} \mathrm{C}$ in $5 \% \mathrm{CO}_{2}$ atmosphere. After 72 hours, supernatants were harvested and analyzed by sandwich ELISA. Values represent means $\pm \mathrm{SEM}$. ${ }^{*} \mathrm{P}<0.05$; ${ }^{* *} \mathrm{P}<0.01$ compared to the control. SLT10, SLT20; silk lutein extract 10 and $20 \mathrm{mg} / \mathrm{kg}$ groups, CLT10, CLT20; marigold lutein extract 10 and $20 \mathrm{mg} / \mathrm{kg}$ groups. enhanced lymphocyte proliferation by silk lutein extract is likely attributable to the increases in total $\mathrm{T}$ and $\mathrm{Th}$ subpopulations as well as to the production of IL-2. In contrast, the marigold lutein extract in our study did not alter the IL-2 level despite stimulated ConA-induced lymphocyte proliferation. Similarly, increased lymphocyte proliferation without IL-2 production has been reported in cats, dogs and mice given marigold lutein extract $[8,11,12]$. In this regard, increased lymphoproliferative response may be mediated by the alterations in the expression of surface molecules such as major histocompatibility complex class II and IL-2 receptors, which are responsible for antigen presentation and clonal expansion, respectively. Taken together, the results of this study suggest that silk lutein extract can enhance $\mathrm{T}$ cell functions, perhaps differently from the marigold lutein extract.

Upon stimulation with sheep erythrocyte antigen, the levels of anti-erythrocyte antibodies in plasma were elevated in mice fed silk lutein extract. Although B 


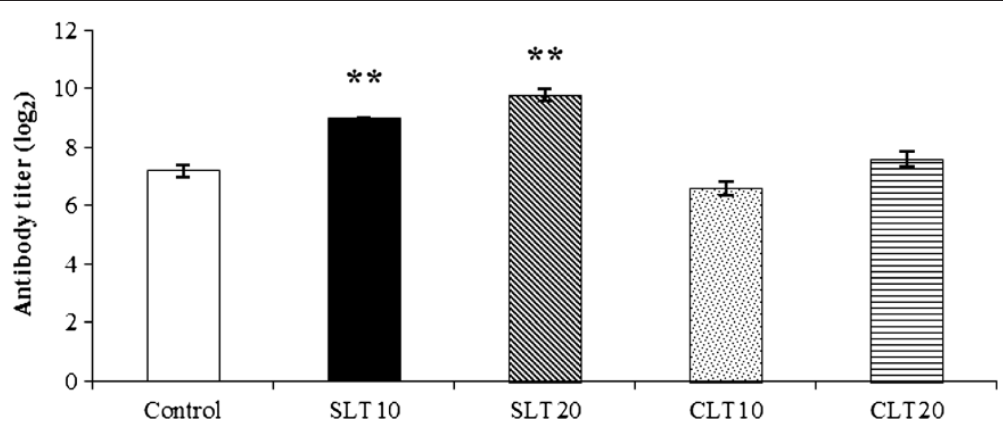

Figure 4 Levels of anti-sheep erythrocyte antibodies in BALB/c mice fed silk lutein extract or marigold lutein extract. A day after cessation of treatment, mice were intraperitoneally injected with sheep erythrocytes as antigens. Second immunization was carried out on day 14 and blood samples were collected 7 days after the boost. Specific anti-sheep erythrocytes antibodies were determined by hemagglutination. Values represent means \pm SEM. ${ }^{*} \mathrm{P}<0.01$ compared to the control. SLT10, SLT20; silk lutein extract 10 and $20 \mathrm{mg} / \mathrm{kg}$ groups, CLT 10, CLT 20; marigold lutein extract 10 and $20 \mathrm{mg} / \mathrm{kg}$ groups.

cell numbers appeared unchanging, it is more likely that the plasma cell functions may have been promoted. The increased concentration of antigen-specific antibodies would thus indicate the enhancement activity of the silk lutein extract on humoral immune system responding to pathogens and other foreign intrusions. This finding is also of clinical significance because silk lutein extract may serve as an adjuvant to help stimulate the antibody production for routine vaccinations. Discovery of new non-toxic adjuvants within the collections of natural products has recently been put forward as an urgent need for producing more efficacious vaccines [24]. While marigold lutein extract failed to show increased antibody titers for mice in this study, such effects have been observed in dogs [11] and cats [12]. Lutein given to dogs and cats was pre-mixed with soybean oil [11] or basal diet containing high fat [12] whereas the mice in this study were fed only with a suspension of lutein. Besides, lutein dosage, species of animals, challenged antigens, and immunization schedules could also possibly contribute to such differences.

The contents of lutein either from silk or marigold extracts given to the animals herein were equivalent. Nevertheless, there are certain differences in the silk and marigold lutein extract preparation in this study. Lutein in the silk extract was predominantly in a free unesterified form whereas most commercial marigold lutein is present in a diesterified form [25]. The silk, but not marigold, extract also contained fats including free fatty acids plus other insoluble wax materials. Until now, it is accepted that in order to achieve its potential beneficial health effects, the carotenoid lutein must be efficiently absorbed and carried to its target tissues. Among dietary factors that influence such bioavailability, fat seems to exert the greatest impact on lutein absorption. This is supported by the fact that the absorption efficiency of lutein increases when the amount of fat in the diet increases [26-30]. Available data have also demonstrated that the bioavailability of lutein is much more sensitive to a fat containing diet than other carotenoids such as $\beta$-carotene. It was shown that $3 \mathrm{~g}$ fat were sufficient for optimum absorption of $\alpha$ - and $\beta$-carotene whereas higher amounts of fat $(36 \mathrm{~g})$ were required for optimum absorption of lutein [26]. Recent studies where types of fatty acids on lutein bioavailability was assessed have also revealed that dietary fats rich in saturated fatty acids lead to a higher bioavailability of lutein [31]. Regarding to this, the presence of fats in the silk extract may promote solubilization and perhaps aid stability of lutein, resulting in the efficient absorption of lutein. Since palmitic and steric acids were the predominant saturated fatty acids identified in the silk extract, these fatty acids would also enhance such a critical step for great bioavailability of lutein. Moreover, the oleic acid in the silk extract may augment such action as this fatty acid has also been reported to modulate the absorption of dietary lutein [32]. Since the unesterified form of lutein has greater bioavailability [33-37], this could additionally explain the preferable effects of the silk lutein extract, in comparison to marigold lutein extract, in the present study. The fact that lutein from the silkworm $B$. mori usually presents in a protein-binding form $[38,39]$ and that bound protein was removed during the extraction process, there is a possibility that the binding site of such lutein remains active and preferentially acts on the target tissues, in different manners to the esterified marigold lutein. Although mechanisms responsible for this remain to be clarified, the evidence described herein could explain, to a certain degree, the differences of immune enhancing outcomes between silk and marigold lutein extracts. The findings in this study support the requirement of fats for lutein, and highlight the importance of the sufficiently suitable fats in silk extract preparation to facilitate absorption before the lutein could efficiently exert its maximal immune activity. 


\section{Conclusions}

In sum of the data, the present study demonstrated that a package of the yellow silk cocoon extract containing naturally occurring lutein and fats was capable of efficiently enhancing both innate and adaptive immune functions. Such silk lutein extract may prove superior to existing plant lutein extract for strengthened immunity and consequent health improvement.

\section{Methods}

\section{Silk lutein extract preparation}

Silk lutein extract was prepared according to the method described in the patent with international publication number WO 2012/091683 A1. Yellow cocoons from the Nangnoi strain of Thai silkworms (Bombyx mori) were first soaked in distilled water at a ratio of 1:30 and then degummed at $121^{\circ} \mathrm{C}$ for 15 minutes to partially remove glutinous silk protein sericin. After being heated, degummed cocoons and degumming solution were separated off, leaving degummed cocoons. Next, the degummed cocoons were fourfold extracted with $30 \mathrm{ml}$ of hexane/ethanol/ethyl acetate $(3: 2: 1, \mathrm{v} / \mathrm{v} / \mathrm{v})$ with $0.1 \%$ butylated hydroxytoluene $(\mathrm{w} / \mathrm{v})$ until colorless. The resulting solution was collected and kept in an amber glass sample bottle at $4^{\circ} \mathrm{C}$. Then, it was partitioned into non-aqueous phase and an aqueous phase by adding $100 \mathrm{ml}$ of aqueous sodium chloride at $10 \%(\mathrm{w} / \mathrm{v})$ into the organic mixture solution. The supernatant was separated from the aqueous phase and evaporated to dryness under vacuum at temperature $\leq 35^{\circ} \mathrm{C}$. The dried residue was dissolved in hexane/ethyl acetate $(3: 1, \mathrm{v} / \mathrm{v})$ to obtain a preferred volume of 5 to $10 \mathrm{ml}$ and then filtered through a $0.45 \mu \mathrm{m}$ PTFE syringe filter to obtain lutein extract. Analysis using UV/VIS spectrophotometer (Libra S22, Biochrom Ltd., UK) revealed the absorption spectrum for lutein in the resulting silk extract, as compared with the authentic lutein standard (Figure 5A). Carotenoids and their compositions in the silk extract were quantified by reversed-phase highperformance liquid chromatography (HPLC; Agilent HP 1100 series). The silk extract contained lutein $5.4 \% \mathrm{w} / \mathrm{w}$ and this represented a major constituent, accounting for $91.26 \%$, of total carotenoids in such extract. The HPLC chromatogram of the silk lutein extract, along with that of the standard lutein, is shown in Figure 5B. As analyzed by gas chromatography, the silk lutein extract also contained free fatty acids $10.41 \% \mathrm{w} / \mathrm{w}$ while the remainder was insoluble unidentified wax materials. The compositions of fatty acids in the silk lutein extract are presented in Table 2. Marigold lutein extract from Tagetes erecta flowers was purchased from P.R. China through TTK Science (Bangkok, Thailand). The marigold extract contained lutein $97.2 \%$, as specified by the manufacturer. Analysis by liquid chromatography-mass spectrometry (LC-MS) using Ultraflex III TOF/TOF (Bruker Daltonik, GmbH) further confirmed identity of lutein in the silk and marigold extracts. LC-MS analysis also displayed Maldi-TOF MS spectra corresponding to kaempherol and quercetin in the marigold extract whereas these flavonoids were not detected in the silk lutein extract (data not shown).

Based on lutein concentration determined by HPLC, the silk lutein extract solubilized in dimethylsulfoxide (DMSO) was dissolved with $1 \%$ tween 80 in phosphate buffered saline (PBS) $\mathrm{pH} 7.4$ to achieve the desired concentrations to be given to the animals. This working lutein solution was prepared weekly and kept at $-20^{\circ} \mathrm{C}$ in sealed containers in the dark under nitrogen gas. Preparation of the marigold lutein extract was performed precisely as described for the silk lutein extract.

\section{Animals and experimental design}

Female BALB/c mice (7 weeks old; 20-23 g) were obtained from the National Laboratory Animal Center, Mahidol University, Thailand. Animals were housed in polycarbonate cages maintained at $25 \pm 1^{\circ} \mathrm{C}$ with a 12 -h dark: light cycle and had free access to sterile water and standard mouse diet (CP Company, Thailand; Table 3). Animal procedures were reviewed and approved by the Animal Research Ethics Committee of Naresuan University, Thailand (Permit Number: 52040007). All animal experiments were conducted in accordance with the institutional guidelines for the care and use of laboratory animals. The mice were randomly assigned to five groups of five animals each and were orally administered via a feeding tube with either: (1) vehicle (1\% Tween 80 in PBS pH 7.4; Controls); (2) $10 \mathrm{mg} / \mathrm{kg}$ body weight of silk lutein extract (SLT10); (3) $20 \mathrm{mg} / \mathrm{kg}$ silk lutein extract (SLT20); (4) $10 \mathrm{mg} / \mathrm{kg}$ commercial lutein marigold extract (CLT10; P.R. China); and (5) $20 \mathrm{mg} / \mathrm{kg}$ commercial lutein marigold extract (CLT20). These dosages were administered once daily for a period of 4 weeks. Animal body weights were recorded weekly and routine clinical observations were carried out throughout the experiments.

Five mice in each group were humanely killed by intraperitoneal injection with an overdose of pentobarbital sodium (Nembutal ${ }^{\mathrm{R}}$, Ceva Sante Animale, France; $40-50 \mathrm{mg} / \mathrm{kg}$ body weight) on week 2 (for assessment of natural killer cell activity) and week 4 (for other immune parameters) after the initial lutein extract administration. The spleens and thymus were removed and weighed immediately. Their indices were expressed as $100 \times$ spleen or thymus weight/ body weight.

\section{Splenic single cell preparation}

After being removed, the spleens were aseptically saved in a PCM buffer prepared with sterile PBS pH 7.4 containing $7 \times 10^{-4} \mathrm{M} \mathrm{CaCl}_{2}, 5 \times 10^{-4} \mathrm{M} \mathrm{MgCl}_{2}, 5 \%$ (v/v) fetal bovine serum (Gibco, South America), $100 \mathrm{U} / \mathrm{ml}$ penicillin, and $100 \mu \mathrm{g} / \mathrm{ml}$ streptomycin (PAA, Pasching, Austria). Single cells were mechanically separated via a cell strainer (BD 


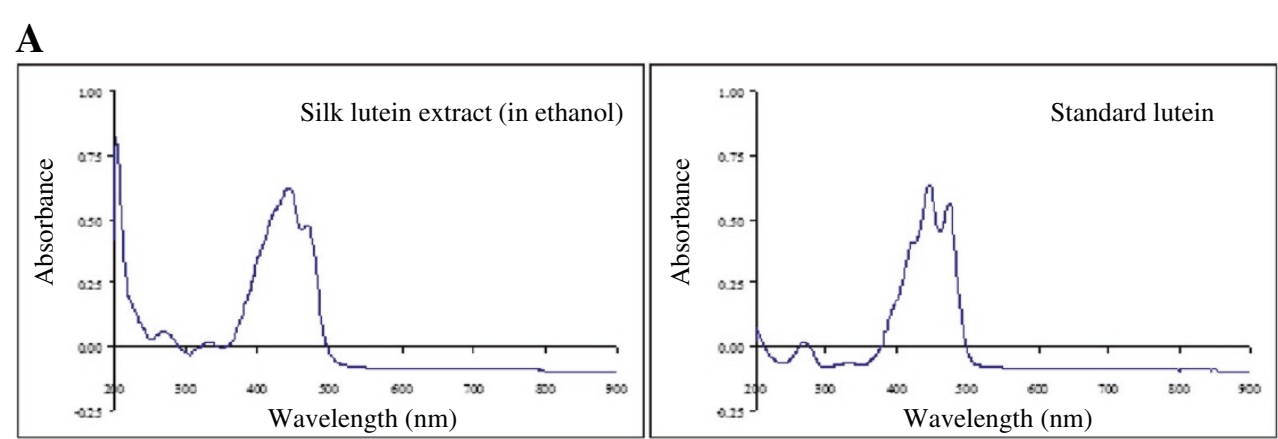

\section{B}
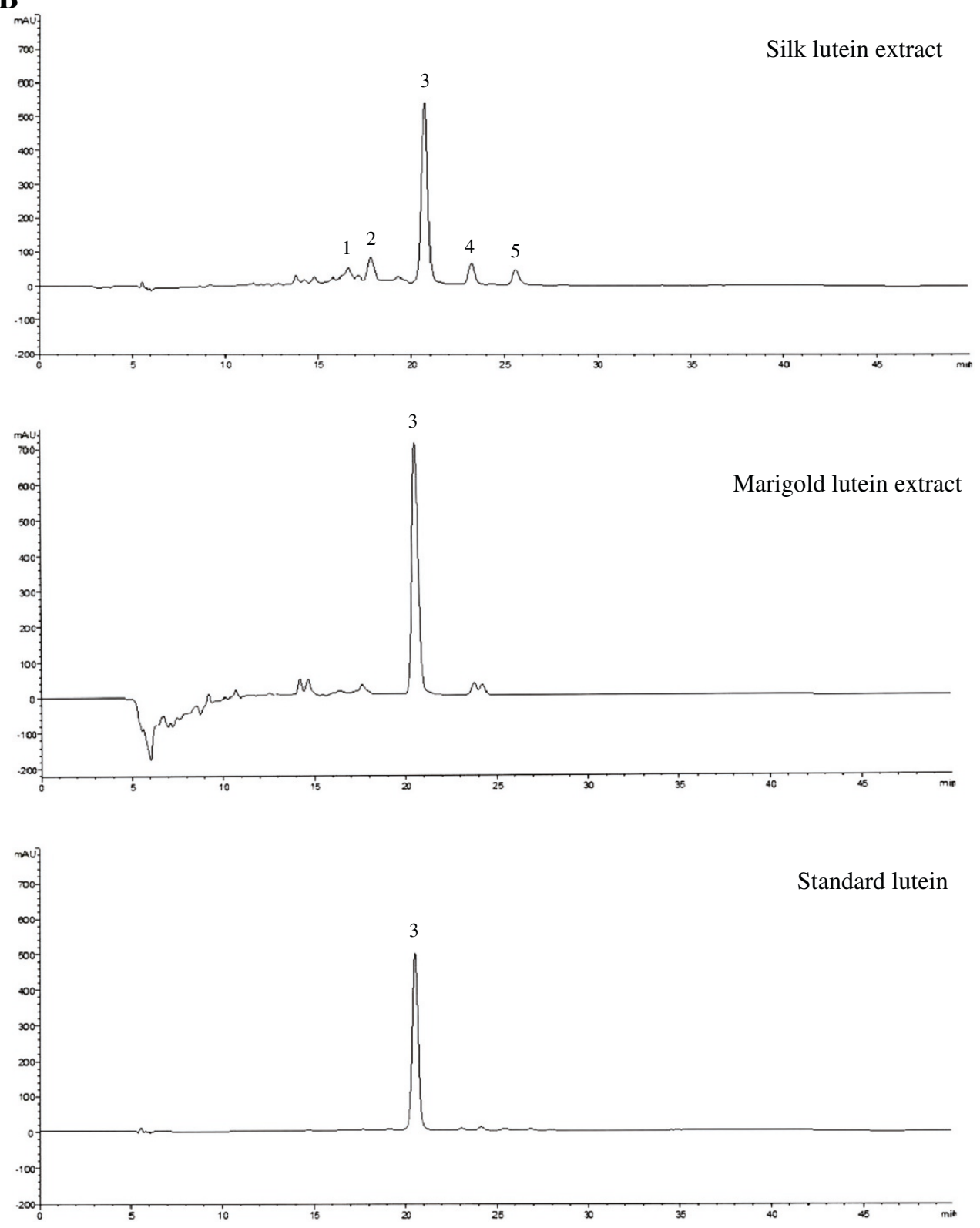

Figure 5 Fingerprints of silk lutein extract, marigold lutein extract and standard lutein (Sigma). (A) UVNIS absorption spectra (B) HPLC chromatograms at $445 \mathrm{~nm}$. HPLC was conducted using a LiChrospher 100 reversed-phase C30 column as stationary and acetonitrile/methanol (9:1, v/V) and ethyl acetate as mobile phases. Peaks: 1, (13-Z)-Iutein; 2, (13'-Z)-lutein; 3, (all-E)-lutein; 4, (9-Z)-Iutein and 5, (9'-Z)-lutein. 
Table 2 Fatty acid compositions of silk lutein extract

\begin{tabular}{|c|c|c|c|c|c|}
\hline Fatty acid & $g / g$ of fat & $\%$ & Fatty acid & $g / g$ of fat & $\%$ \\
\hline Capric acid & 0.0005 & 0.05 & Alpha Linolenic acid & 0.0056 & 0.56 \\
\hline Lauric acid & 0.0010 & 0.10 & Arachidic & 0.0027 & 0.27 \\
\hline Myristic acid & 0.0013 & 0.13 & cis-11-Eicosenoic acid & 0.0002 & 0.02 \\
\hline Pentadecanoic acid & 0.0002 & 0.02 & $c 9, \mathrm{t} 11$ & 0.0002 & 0.02 \\
\hline Palmitic acid & 0.0197 & 1.97 & $c 9, c 11$ & 0.0006 & 0.06 \\
\hline Palmitoleic acid & 0.0009 & 0.09 & cis-11,14-Eicosedienoic acid & 0.0001 & 0.01 \\
\hline Stearic acid & 0.0161 & 1.61 & cis-8,11,14-Eicosatrienoic acid & 0.0037 & 0.37 \\
\hline Elaidic & 0.0007 & 0.07 & Behenic & 0.0018 & 0.18 \\
\hline Oleic acid & 0.0290 & 2.90 & cis-4,7,10,13,1 6,19-Docosahexaenoic acid & 0.0017 & 0.17 \\
\hline Linoleic acid & 0.0137 & 1.37 & Erucic & 0.0015 & 0.15 \\
\hline Gamma-Linolenic acid & 0.0005 & 0.05 & Lignoceric & 0.0024 & 0.24 \\
\hline
\end{tabular}

${ }^{1}$ Fatty acid compositions were analyzed by gas chromatography (Hewlett Packard GC system HP6890 A; Hewlett Packard, PA) equipped with a $100 \mathrm{~m} \times 0.25$ mm fused silica capillary column (SP2560, Supelco Inc, Bellefonte, PA). Injector and detector temperatures were set at $250^{\circ} \mathrm{C}$. The column temperature was kept at $4^{\circ} \mathrm{C}$ for $4 \mathrm{~min}$, then increased at $13^{\circ} \mathrm{C} / \mathrm{min}$ to $175^{\circ} \mathrm{C}$ and held at $175^{\circ} \mathrm{C}$ for $7 \mathrm{~min}$, then increased at $4^{\circ} \mathrm{C} / \mathrm{min}$ to $215^{\circ} \mathrm{C}$ and held at $215^{\circ} \mathrm{C}$ for $17 \mathrm{~min}$.

Falcon, NJ). Erythrocytes were removed by lysis in $0.17 \mathrm{M}$ $\mathrm{NH}_{4} \mathrm{Cl} \mathrm{pH} 7.65$, and the resulting cell suspensions were washed twice with a PCM buffer by centrifugation. Cell pellets were finally resuspended with RPMI-1640 (PAA) containing $10 \%(\mathrm{v} / \mathrm{v})$ fetal bovine serum, 0.01 M HEPES $\mathrm{pH} 7.4,5 \times 10^{-5} \mathrm{M} \beta$-mercaptoethanol (BioRad, Hercules, CA), $2 \mathrm{mM}$ L-glutamine, $100 \mathrm{U} / \mathrm{ml}$ penicillin and $100 \mu \mathrm{g} / \mathrm{ml}$ streptomycin. The viability of the splenic cells was determined by trypan blue dye exclusion using a hemocytometer.

\section{Natural killer cell activity}

Splenic natural killer (NK) cell activity was evaluated by 3-(4,5-dimethylthiazol-2-yl)-2,5-diphenyltetrazolium bromide (MTT) assay as previously described [40,41]

Table 3 Nutritional composition of mice feed

\begin{tabular}{llll}
\hline Component & Amount & Component & Amount \\
\hline Moisture & $12 \%$ & Vitamin A & $20,000 \mathrm{i.u} . / \mathrm{kg}$ \\
Crude protein & $24 \%$ & Vitamin D & $4,000 \mathrm{i} . \mathrm{u} . / \mathrm{kg}$ \\
Fat & $4.5 \%$ & Vitamin E & $100 \mathrm{mg} / \mathrm{kg}$ \\
Fiber & $5 \%$ & Vitamin K & $5 \mathrm{mg} / \mathrm{kg}$ \\
Calcium & $1 \%$ & Vitamin B1 & $20 \mathrm{mg} / \mathrm{kg}$ \\
Phosphorus & $0.9 \%$ & Vitamin B2 & $20 \mathrm{mg} / \mathrm{kg}$ \\
Sodium & $0.2 \%$ & Vitamin B6 & $20 \mathrm{mg} / \mathrm{kg}$ \\
Potassium & $1.17 \%$ & Vitamin B12 & $0.036 \mathrm{mg} / \mathrm{kg}$ \\
Magnesium & $0.23 \%$ & Niacin & $100 \mathrm{mg} / \mathrm{kg}$ \\
Manganese & 171 p.p.m. & Folic acid & $6 \mathrm{mg} / \mathrm{kg}$ \\
Copper & 22 p.p.m. & Biotin & $0.4 \mathrm{mg} / \mathrm{kg}$ \\
Zinc & 100 p.p.m. & Pantothenic acid & $60 \mathrm{mg} / \mathrm{kg}$ \\
Iron & 180 p.p.m. & Choline chloride & $1,500 \mathrm{mg} / \mathrm{kg}$ \\
Cobalt & 1.82 p.p.m. & Metabolizable energy & $3,040 \mathrm{kcal} / \mathrm{kg}$ \\
Potassium iodide & 1 p.p.m. & & \\
Selenium & 0.1 p.p.m. & & \\
\hline
\end{tabular}

with few modifications. Briefly, splenic cells (effector cells), prepared as described above, and YAC-1 cells (target cells; American Type Culture Collection, Manassas, VA) were incubated together in 96-well flat-bottom plates $\left(\mathrm{Nunc}^{\mathrm{R}}\right.$ ) (effector: target ratio of 100:1) with a total volume of $200 \mu \mathrm{l}$ in each well. The plates were incubated at $37^{\circ} \mathrm{C}$ in a humidified $5 \% \mathrm{CO}_{2}$ atmosphere. After 20 hours, $100 \mu \mathrm{l}$ of the culture supernatants were removed and $40 \mu \mathrm{l}$ of MTT ( $5 \mathrm{mg} / \mathrm{ml}$; Sigma, St. Louis, MO) was added. After an additional 3 hours of incubation, the plates were subjected to an MTT assay [42]. Control wells contained either effector or target cells alone, and all tests were performed in triplicate. The optical density (OD) at $540 \mathrm{~nm}$ was determined by using a microplate spectrophotometer (Labsystem iEM Reader MF). The percentage of NK cell cytotoxic activity was calculated according to the formula: $\{1-[(O D$ test OD effector cell control) / OD target cell control] $\} \times 100$.

\section{Splenic lymphocyte subpopulations}

The percentages of lymphocyte subpopulations in the spleen were quantified by Flow cytometry. Splenic single cell suspensions $\left(4 \times 10^{5}\right.$ cells) were stained for 30 minutes on ice with fluorescently conjugated antibodies specific for the mouse $\mathrm{T}$ cell markers $\mathrm{CD} 3, \mathrm{CD} 4$ and $\mathrm{CD} 8$, and for the mouse B cell markers CD21/35. Fluorescein isothiocyanate conjugated anti-mouse CD3e (clone eBio500A2), phycoerythrin $(\mathrm{PE})$ conjugated anti-mouse $\mathrm{CD} 4$ (clone RM4-5), PE conjugated anti-mouse CD8a (clone 53-6.7), and $\mathrm{PE}$ conjugated anti-mouse CD21/CD35 (clone eBio8D9) were all purchased from eBioscience (San Diego, CA). Appropriate isotype-matched antibodies were used as controls for background staining. Stained cells were washed twice with cold-PBS containing $2 \%$ fetal bovine serum and then fixed with $1 \%$ paraformaldehyde. Cells were then analyzed with a Becton Dickinson FACScalibur and 
CellQuest Pro software (Becton Dickinson). A total of 5,000 events were acquired for each analysis.

\section{Mitogen-induced lymphocyte proliferation}

The proliferation of splenic lymphocytes in response to $\mathrm{T}$ and $\mathrm{B}$ cell mitogens was determined by MTT assay [42]. A total of $2 \times 10^{5}$ splenic cells were cultured in flat-bottom 96-well plates $\left(\mathrm{Nunc}^{\mathrm{R}}\right)$ in the presence or absence of Concanavalin A (ConA, $0.5 \mu \mathrm{g} / \mathrm{ml}$; Sigma) or lipopolysaccharide (LPS, $2.5 \mu \mathrm{g} / \mathrm{ml}$; Sigma) and incubated at $37^{\circ} \mathrm{C}$ in a $5 \% \mathrm{CO}_{2}$ atmosphere. After 48 hours, $20 \mu \mathrm{l}$ of MTT $(5 \mathrm{mg} / \mathrm{ml})$ was added and the plates were incubated for another 4 hours. Supernatant in each well was discarded, and $100 \mu \mathrm{l}$ of DMSO was added to dissolve the formazan crystals. The OD at $540 \mathrm{~nm}$ of each well was measured on a microplate spectrophotometer (Labsystem iEM Reader MF). All assay tests were done in triplicate.

\section{Cytokine production}

The production of regulatory cytokines caused by splenic lymphocytes was determined by sandwich enzyme-linked immunosorbent assay (ELISA) using Ready-Set-Go for mouse IL-2, IFN- $\gamma$, IL-4 and IL-10 (eBioscience). All assay procedures were performed according to the manufacturers' instructions. A total of $2 \times 10^{5}$ splenic cells were cultured in flat-bottom 96-well plates $\left(\mathrm{Nunc}^{\mathrm{R}}\right)$ in the presence of Con A $(0.5 \mu \mathrm{g} / \mathrm{ml}$ for interferon- $\gamma$ (IFN- $\gamma)$, interleukin-4 (IL-4) and interleulin-10 (IL-10), and $2.5 \mu \mathrm{g} / \mathrm{ml}$ for interleukin-2 (IL-2). After incubating the cells at $37^{\circ} \mathrm{C}$ in $5 \% \mathrm{CO}_{2}$ atmosphere for 72 hours, the cultured supernatants were collected and stored at $-20^{\circ} \mathrm{C}$ until assayed. The detection limits were $2,15,4$, and $30 \mathrm{pg} / \mathrm{ml}$ for IL-2, IFN- $\gamma$, IL-4, and IL-10, respectively.

\section{In vivo antibody response}

Humoral immune response was assessed through an immunization protocol with sheep erythrocytes as antigens. A day after ceasing treatment, the mice were intraperitoneally injected with $2 \times 10^{8}$ erythrocytes in $0.2 \mathrm{ml}$ saline solution. A second immunization was carried out on day 14 and blood samples were collected 7 days after the boost. Specific anti-sheep erythrocytes antibodies were determined by hemagglutination. The reciprocal serum dilution with $\geq 50 \%$ agglutination was considered to be the titer.

\section{Statistical analysis}

Data are expressed as mean \pm SEM. The differences among groups were evaluated by one-way analysis of variance (ANOVA), followed by Tukey's Honestly Significant Difference test. All statistical analyses were performed with SPSS version 11.5 (SPSS Inc., Chicago, IL). Differences were considered to be significant at $\mathrm{P}<0.05$.
Competing interests

No competing financial interests exist.

\section{Authors' contributions}

PP was responsible for conducting the experiments, data acquisition and analysis, and helped to design the experiments. SB carried out some immunoassays. MS was responsible for silk lutein extraction and component analysis of the extract, and involved in revision of manuscript. DK was responsible for experimental design, acquisition, analysis and interpretation of data, drafting and revising the manuscript. All authors read and approved the final manuscript.

\section{Acknowledgements}

This study was financially supported by the Agricultural Research Development Agency (Public Organization). The authors thank Sang Sriampri for technical assistance in Flow cytometric analysis. Special thanks also to Dr. Sittiruk Roytrakul for LC-MS analysis.

\section{Author details}

'Department of Biology, Faculty of Science, Naresuan University, Phitsanulok 65000, Thailand. ${ }^{2}$ Department of Microbiology and Parasitology, Faculty of Medical Science, Naresuan University, Phitsanulok 65000, Thailand. ${ }^{3}$ School of Food Technology, Institute of Agricultural Technology, Suranaree University of Technology, Nakhon Ratchasima 30000, Thailand. ${ }^{4}$ Centre of Excellence in Medical Biotechnology, Faculty of Medical Science, Naresuan University, Phitsanulok 65000, Thailand.

Received: 17 April 2014 Accepted: 21 April 2014

Published: 28 April 2014

\section{References}

1. Chew BP, Park JS: Carotenoid action on the immune response. J Nutr 2004, 134:257S-261S.

2. Carpentier S, Knaus M, Suh M: Associations between lutein, zeaxanthin, and age-related macular degeneration: an overview. Crit Rev Food Sci Nutr 2009, 49:313-326.

3. Chiu CJ, Taylor A: Nutritional antioxidants and age-related cataract and maculopathy. Exp Eye Res 2007, 84:229-245.

4. Weigert G, Kaya S, Pemp B, Sacu S, Lasta M, Werkmeister RM: Effects of lutein supplementation on macular pigment optical density and visual acuity in patients with age-related macular degeneration. Invest Ophthalmol Vis Sci 2011, 52:8174-8178.

5. Arnal E, Miranda M, Almansa I, Muriach M, Barcia JM, Romero FJ: Lutein prevents cataract development and progression in diabetic rats. Graefes Arch Clin Exp Ophthalmol 2009, 247:115-120.

6. Roberts RL, Green J, Lewis B: Lutein and zeaxanthin in eye and skin health. Clin Dermatol 2009, 27:195-201.

7. Reynoso-Camacho R, Gonzalez-Jasso E, Ferriz-Martinez R, Villalon-Corona B, Loarca-Pina GF, Salgado LM: Dietary supplementation of lutein reduces colon carcinogenesis in DMH-treated rats by modulating $\mathrm{K}$-ras, $\mathrm{PKB}$, and $\beta$-catenin proteins. Nutr Cancer 2011, 63:39-45.

8. Chew BP, Wong MW, Wong TS: Effects of lutein from marigold extract on immunity and growth of mammary tumors in mice. Anticancer Res 1996, 16:3689-3694.

9. Rock CL, Saxe GA, Ruffin MT IV, August DA, Schottenfeld D: Carotenoids, vitamin $A$, and estrogen receptor status in breast cancer. Nutr Cancer 1996, 25:281-296.

10. Jyonouchi H, Zhang L, Gross M, Tomita Y: Immunomodulating actions of carotenoids: enhancement of in vivo and in vitro antibody production to T-dependent antigens. Nutr Cancer 1994, 21:47-58.

11. Kim HW, Chew BP, Wong TS, Park JS, Weng BB, Byrne KM: Dietary lutein stimulates immune response in the canine. Vet Immunol Immunopathol 2000, 74:315-327.

12. Kim HW, Chew BP, Wong TS, Park JS, Weng BB, Byrne KM: Modulation of humoral and cell-mediated immune responses by dietary lutein in cats. Vet Immunol Immunopathol 2000, 73:331-341.

13. McGraw KJ, Ardia DR: Carotenoids, immunocompetence, and the information content of sexual colors: an experimental test. Am Nat 2003, 162:704-712. 
14. Kelly JP, Kaufman DW, Kelley K, Rosenberg L, Anderson TE, Mitchell AA: Recent trends in use of herbal and other natural products. Arch Intern Med 2005, 165:281-286.

15. Larson T, Coker J: A descriptive study of lutein and zeaxanthin in optometric practice. Optometry 2009, 80:579-586.

16. Meleth AD, Gensler G, Clemons TE, SanGiovanni JP, Chew EY: Age-Related Eye Disease Study 2 (AREDS2) Research Group: baseline nutritional characteristics of the Age-Related Eye Disease Study 2 (AREDS2) cohort. Invest Ophthalmol Vis Sci 2009, 50:279.

17. Calvo MM: Lutein: a valuable ingredient of fruit and vegetables. Crit Rev Food Sci Nutr 2005, 45:671-696.

18. Fernandez-Sevilla JM, Acien Fernandez FG, Molina Grima E: Biotechnological production of lutein and its applications. Appl Microbiol Biotechnol 2010, 86:27-40.

19. Tsao R, Yang R: Lutein in selected Canadian crops and agri-food processing by-products and purification by high-speed counter-current chromatography. J Chromatogr A 2006, 1112:202-208.

20. Prommuak C, De-Eknamkul W, Shotiprik A: Extraction of flavonoids and carotenoids from Thai silk waste and antioxidant activity of extracts. Sep Purif Technol 2008, 62:444-448.

21. Tabunoki H, Higurashi S, Ninagi O, Fujii H, Banno Y, Nozaki M: A carotenoidbinding protein (CBP) plays a crucial role in cocoon pigmentation of silkworm (Bombyx mori) larvae. FEBS Lett 2004, 567:175-178.

22. Promphet $P$, Bunarsa S, Kongbangkerd A, Sutheerawattananonda M, Kunthalert D: Alteration of lymphocyte subpopulations in mice fed lutein from marigold extract. Sci Res Essays 2013, 8:22-25.

23. Lee CM, Boileau AC, Boileau TWM, Williams AW, Swanson KS, Heintz KA: Review of animal models in carotenoid research. J Nutr 1999, 129:2271-2277.

24. Rey-Ladino J, Ross AG, Cripps AW, McManus DP, Quinn R: Natural products and the search for novel vaccine adjuvants. Vaccine 2011, 29:6464-6471.

25. Tsao R, Yang R, Young JC, Zhu H, Manolis T: Separation of geometric isomers of native lutein diesters in marigold (Tagetes erecta L.) by high-performance liquid chromatography-mass spectrometry. J Chromatogr A 2004, 1045:65-70.

26. Roodenburg AJC, Leenen $\mathrm{R}$, van het Hof KH, Weststrate JA, Tijburg LBM: Amount of fat in the diet affects bioavailability of lutein esters but not a-carotene, $\beta$-carotene, and vitamin E in humans. Am J Clin Nutr 2000, 71:1187-1193.

27. Van Het Hof KH, West CE, Weststrate JA, Hautvast JG: Dietary factors that affect the bioavailability of carotenoids. J Nutr 2000, 130:503-506.

28. Chung HY, Rasmussen HM, Johnson EJ: Lutein bioavailability is higher from lutein-enriched eggs than from supplements and spinach in men. $J$ Nutr 2004, 134:1887-1893.

29. Unlu NZ, Bohn T, Clinton SK, Schwartz SJ: Carotenoid absorption from salad and salsa by humans is enhanced by the addition of avocado or avocado oil. J Nutr 2005, 135:431-436.

30. Yonekura L, Nagao A: Intestinal absorption of dietary carotenoids. Mol Nutr Food Res 2007, 51:107-115.

31. Gleize B, Tourniaire F, Depezay L, Bott R, Nowicki M, Albino L: Effect of type of TAG fatty acids on lutein and zeaxanthin bioavailability. Br J Nutr 2013, 110:1-10.

32. Lakshminarayana R, Raju M, Krishnakantha TP, Baskaran V: Lutein and zeaxanthin in leafy greens and their bioavailability: olive oil influences the absorption of dietary lutein and its accumulation in adult rats. J Agric Food Chem 2007, 55:6395-6400

33. Zaripheh S, Erdman JW: Factors that influence the bioavailablity of xanthophylls. J Nutr 2002, 132:531S-534S.

34. Breithaupt DE, Bamedi A, Wirt U: Carotenol fatty acid esters: easy substrates for digestive enzymes? Comp Biochem Physiol B Biochem Mol Biol 2002, 132:721-728.

35. Alves-Rodrigues A, Shao A: The science behind lutein. Toxicol Lett 2004, 150:57-83.

36. Perez-Galvez A, Minguez-Mosquera Ml: Esterification of xanthophylls and its effect on chemical behavior and bioavailability of carotenoids in the human. Nutr Res 2005, 25:631-640.

37. Norkus EP, Norkus KL, Dharmarajan TS, Schierle J, Schalch W: Serum lutein response is greater from free lutein than from esterified lutein during 4 weeks of supplementation in healthy adults. J Am Coll Nutr 2010, 29:575-585.

38. Tabunoki H, Sugiyama H, Tanaka Y, Fujii H, Banno Y, Jouni ZE: Isolation, characterization, and CDNA sequence of a carotenoid binding protein from the silk gland of Bombyx mori larvae. J Biol Chem 2002, 277:32133-32140.

39. Jouni ZE, Wells MA: Purification and characterization of a lutein-binding protein from the midgut of the silkworm (Bombyx mori). J Biol Chem 1996, 271:14722-14726.

40. Choi EM, Kim A, Kim YO, Hwang JK: Immunomodulating activity of arabinogalactan and fucoidan in vitro. J Med Food 2005, 8:446-453.

41. Yuan C, Huang X, Cheng L, Bu Y, Liu G, Yi F: Evaluation of antioxidant and immune activity of Phellinus ribis glucan in mice. Food Chem 2009, 115:581-584.

42. Mosmann T: Rapid colorimetric assay for cellular growth and survival: application to proliferation and cytotoxicity assays. J Immunol Methods 1983, 65:55-63.

doi:10.1186/0717-6287-47-15

Cite this article as: Promphet et al:: Immune enhancement activities of silk lutein extract from Bombyx mori cocoons. Biological Research 2014 47:15.

\section{Submit your next manuscript to BioMed Central and take full advantage of:}

- Convenient online submission

- Thorough peer review

- No space constraints or color figure charges

- Immediate publication on acceptance

- Inclusion in PubMed, CAS, Scopus and Google Scholar

- Research which is freely available for redistribution 